\title{
Revisiting the Borrowability Scale(s) of Free Grammatical Elements: Evidence from Modern Greek Contact induced Varieties
}

\author{
Dimitra Melissaropoulou \\ Aristotle University of Thessaloniki \\ dmelissa@itl.auth.gr \\ Angela Ralli \\ University of Patras \\ ralli@upatras.gr
}

\begin{abstract}
This article aims to test the general validity of borrowability scales by investigating contrastively two contact induced linguistic varieties of Greek. It tries to elucidate the factors that facilitate or inhibit the borrowability of free grammatical elements, which are usually considered as less amenable to transfer. It argues against the formulation of any borrowability scales of a generalized predictive power, even in cases where there is a common denominator. It suggests that factors such as the (in)compatibility between the two languages in contact, specific re-arrangements brought to the replica language, and the category of the items under investigation play a key role for the adoption of free grammatical elements. It demonstrates that while borrowability of free grammatical elements is not shown to be an exact mirroring of their ranking on the cline of lexicality-grammaticality, general tendencies seem to be at play.
\end{abstract}

\section{Keywords}

language contact - borrowability scale(s) - free grammatical elements - dialectal varieties - Modern Greek 
Borrowability of a wide range of grammatical categories and category domains is admittedly a hotly debated issue in current language-contact studies. Several borrowability hierarchies, also termed borrowability scales, have been formulated to measure likelihood of borrowing by comparing languages in a systematic way, on the basis of specific case studies. They bear temporal, implicational, quantitative and probabilistic interpretations, irrespectively of the typology of the languages under examination, and thus, they advocate a universal approach to borrowing. ${ }^{1}$ In fact, borrowability hierarchies are of great interest, since they open a different window to the investigation of parameters of contact induced change and the constraints that govern the types of borrowed structures. In this spirit, they often account for the factors that enhance or inhibit contact induced change, such as the intensity of contact and the degree of bilingualism (cf. Thomason and Kaufman, 1988; Thomason, 2001), the structural (in)compatibility of the involved systems (cf. Myers-Scotton, 2002; Field, 2002), or the semantic-pragmatic features of the affected categories (cf. Matras, 2007, 2010).

This article aspires to enhance understanding of the parameters that facilitate or inhibit borrowability of free grammatical elements, which are usually thought of being less borrowable due to their nature as structurally cohesive, closed-class items. It tests the validity of borrowability scales by investigating contrastively two contact-induced linguistic systems, which are varieties of the same language, that is, Modern Greek (hereafter Greek). The data ${ }^{2}$ come from Cappadocian Greek (hereafter Cappadocian), which is in contact with the agglutinative Turkish, and Griko being in contact with the semi-fusional IndoEuropean Italo-Romance. ${ }^{3}$ In what follows, we conduct a contrastive analysis of the borrowability of free grammatical elements, which share a common origin and have been in similar settings of long-term intense contact with systems of divergent genetic and typological profile.

1 See, among others, Haugen, 1950, 1951; Moravçsik, 1975, 1978; Muysken, 1981; Thomason and Kaufman, 1988; Campbell, 1993; Thomason, 2001; Field, 2002; Winford, 2003; Elsík and Matras, 2006; Matras, 2007, 2009.

2 The data under investigation are extracted from available written sources (among others, Tommasi, 1996; Stomeo, 1996; Karanastasis, 1997; Rohlfs, 1977; Cassoni, 1999; Filieri, 2001; Dawkins, 1916; Mavrochalyvides, 1990; Janse forthcoming), as well as from the oral corpora of the Laboratory of Modern Greek dialects (http://lmgd.philology.upatras.gr) of the University of Patras.

3 For a comparative study on the contact of Spanish with three typologically divergent languages see Bakker et al., 2008. 
The article is organized as follows: after the introduction, the basic premises and assumptions are summarized on borrowability hierarchies and borrowing of free grammatical elements. Section 3 provides a brief overview of the historical and sociolinguistic background of the examined varieties, followed by a contrastive presentation of the dialectal data (section 4). Section 5 offers a discussion and a profound examination of each different grammatical category and specific claims and proposals are put forward in order to account for the observed divergence between two borrowability scales. The article ends with the major conclusions concerning the borrowability of free grammatical elements and the formulation of corresponding scales and a list of relevant references.

In recent language-contact studies a more or less established view is summarized in Thomason and Kaufman's (1988:14) 'anything goes' position, according to which "[...] as far as the strictly linguistic possibilities go any linguistic feature can be transferred from any language to any other language."4 However, not all linguistic features are equally subject to contact induced transfer. That is why several hierarchies, well known as borrowability scales, have been proposed, allowing for generalizations with respect to the susceptibility of various linguistic categories to contact induced change. For instance, borrowability hierarchies lead to predictions that unbound forms are more borrowable than bound ones, lexical items more borrowable than grammatical items, semantically transparent forms more borrowable than semantically opaque ones, etc.

With respect to borrowability of grammatical elements, the first scale was formulated by Whitney (1881) in terms of a continuum, being part of a broader scale of linguistic borrowing involving not only grammatical but lexical material as well:

(i) Grammatical borrowing

\begin{tabular}{c|c}
\multicolumn{2}{c}{ Grammatical borrowing } \\
Function words & Affixes \\
\hline Prepositions $>$ Conjunctions $>$ Pronouns &
\end{tabular}

Whitney (1881)

4 This position runs against the so-called 'retentionist' one, according to which the transfer of linguistic features from one language to another is feasible if the two languages are typologically similar (cf. Meillet 1921: 82). 
However, the most influential borrowability scales, based on the frequency of borrowed items, have been put forward by Haugen (1950: 224) for Norwegian and Swedish immigrant speech in the US, and Muysken (1981) for Spanish of Quechua speakers.

(ii) nouns $>$ verbs $>$ adjectives $>$ adverbs, prepositions, interjections ${ }^{5}$ Haugen (1950)

(iii) nouns $>$ adjectives $>$ verbs $>$ prepositions $>$ coordinating conjunctions $>$ quantifiers $>$ determiners $>$ free pronouns $>$ clitic pronouns $>$ subordinating conjunctions

Muysken (1981)

More recently, Matras (2007: 61) proposed a somehow different hierarchy, also based on frequency, by investigating a sample of 27 languages. ${ }^{6}$

(iv) Nouns, conjunctions $>$ verbs $>$ discourse markers $>$ adjectives $>$ interjections $>$ adverbs $>$ other particles, adpositions $>$ numerals $<$ pronouns $>$ derivational affixes $>$ inflectional affixes

Matras (2007)

As can be deduced from the above, the suggested hierarchies are not identical in the listing of specific linguistic categories, both lexical and grammatical. For example, adjectives follow verbs according to Haugen (1950), while they precede verbs according to Muysken (1981). Moreover, conjunctions and discourse markers are placed on the highest position according to Matras (2007) outranking even verbs and adjectives as lexical categories - while Muysken (1981) states that coordinating conjunctions are less prone to borrowing.

For the purposes of this study, we focus on the borrowability of free grammatical elements ('function words' cf. Stranzy 2005: 362-364), which are often argued to make a transition between the lexicon and the grammar or between content words and affixes. Admittedly, they form the most diverse group, since

5 Even though lexical and bound elements do not fall within the purposes of this paper, they are mentioned for reasons of completeness, being essential for a full account of the abovementioned hierarchies.

6 The hierarchy proposed by Matras (2007) is shaped following the number of those languages in the sample that show borrowing of the relevant categories. 
they represent a wide range of functions and distributional characteristics. As noted by Field (2002: 62), "[...] function words are distributed into either nominal or verbal structures or occupy positions along phrasal or clausal boundaries." Pronouns, for example, form part of the nominal structure, auxiliary verbs are thought to be subsidiary to lexical verbs, while adpositions and various types of connectors (coordinating and subordinating conjunctions, complementizers etc.) are considered to link elements and indicate logical relations (cf. Field 2002: 63). What they have in common is that they are phonologically independent words, being members of closed classes. Grouping them together does not imply that they all share the same properties or show the same type of behaviour in situations of language contact. However, a tentative hypothesis would be to propose a common cline of borrowability, formulated on the basis of their cline of lexicality / grammaticality (cf. Jackson, 1988).

As no large searchable (on line) corpus or a database for the investigated dialectal varieties is available, allowing us to conduct a data driven or a corpus based study on the borrowability of various grammatical categories, we restrict ourselves to the following unbound grammatical elements/lexemes that can be detected in the available oral and written sources and checked in the available grammatical descriptions in terms of type frequency. ${ }^{7}$

i. adverbials denoting spatial deixis, temporal deixis, quantification, etc.

ii. conjunctions

iii. particles (question, answer, negation, and others)

iv. adpositions

v. numerals

vi. pronouns

vii. determiners

viii. auxiliaries

Note that, in the category of adverbials, we do not include adverbs of manner derived from adjectival bases through suffixation, since they do not constitute real grammatical elements but belong to the lexicon and are formed by a word-formation process. For instance, Greek adverbs in - $a$, like kala 'well', derive from adjectival stems (e.g. kal(os) $)^{8}$ 'good').

7 Although interjections often form part of some of the existing borrowability scales (cf. Haugen 1950 contra Muysken 1981), they are not included in the present study, because they were neither easily nor symmetrically detectable in the available sources due to their debatable status as grammatical category and their onomatopoeic characteristics. 
It is worth noting that the concrete realization of grammatical categories in a given language may not have an exact linguistic equivalent in other language(s) involved in a contact situation. Thus, it is the task of linguists to sort out how the structural realization of a borrowed grammatical element is accommodated in different linguistic systems (contact-induced grammaticalization in terms of Heine and Kuteva 2005). Crucially, in our view, this kind of contact induced transfer between divergent systems is of major importance for determining the borrowability of free grammatical elements and aspires to a profound understanding of the parameters that enhance or facilitate borrowing among linguistic systems. As Stolz (2008: 25-26) asserts, given the fact that in each language a different combination of linguistic features exists, we expect that a borrowed element would be accommodated according to the structural features of the language under examination. ${ }^{9}$ Thus, a major issue to be addressed is why divergent linguistic systems may follow the same path for accommodating a particular feature (cf. Stolz 2008: 26).

Lastly, although we are sceptical about the formulation of absolute constraints, we find that it is really tempting to investigate whether the formulation of scenario-specific and probabilistic constraints [of borrowability hypotheses] is feasible, along the lines of Muysken (2010: 271). A contrastive analysis of the borrowability of free grammatical elements, which share a common linguistic inheritance and have been in long-term intense contact with systems of divergent genetic and typological profile, may provide the appropriate empirical ground in order to test the validity of such formulations.

\section{Historical and Sociolinguistic Background of the Investigated} Systems

\subsection{Cappadocian: a Brief Description}

The Greek speaking Cappadocia in Central Asia Minor came under the Turkish influence during the late Byzantine period, for the first time in the $11^{\text {th }}$ century ${ }^{10}$ after the Seljuk invasion (cf. Vryonis 1971: 448-452), and subsequently in the $15^{\text {th }}$ century after the conquest of the area by the Ottoman Turks. From that

8 In this article, Greek words are given in a broad phonological transcription and inflectional material following Greek stems is noted in parenthesis.

9 See Ralli (2016) on how verbs from the typologically divergent Turkish and Romance are integrated in several Modern Greek varieties, following the requirements of Greek morphology.

10 More specifically, when the Byzantine Empire lost control of the Asia Minor area, after being defeated by the Seljuk Turks in the battle of Manzikert in 1071. 
period, Cappadocian was found in a situation of regressive bilingualism, since Turkish was the dominant language of the political authorities and was spoken by the overwhelming majority of the population in all aspects of life (cf. Vryonis 1971: 457-459). As a consequence, in some communities, total turkicisation and language shift has been reported to have taken place by the end of the $19^{\text {th }}$ century (cf. Sarantidis 1899: 126; Dawkins 1916:11, 14, 18). Although in a situation of intense language contact, Cappadocian was nevertheless preserved in an area that covered approximately 32 communities. The situation changed in 1924, at the time of exchange of populations that followed the end of the GreekTurkish war and the Lausanne treaty (July 1923). Today, it is spoken by descendants of Cappadocian refugees of the communities of Misti and Axos (secondand third-generation refugees) in certain parts of Northern Greece (Kavala, Alexandroupoli, Kilkis, Thessaloniki, Karditsa, Volos, Larisa).

The dialect is divided into three basic groups, North, Central and South Cappadocian (cf. Dawkins, 1916; Janse, forthcoming), showing intra-dialectal divergence.

It is worth noting that Cappadocian is often used in linguistic literature as a prototypical example of 'heavy borrowing' in terms of Thomason and Kaufman's (1988: 50) borrowing scale, due to an 'overwhelming long-term socio-cultural pressure'. Some of its significant linguistic innovations usually attributed to language contact are the following:
a) certain agglutinative-like inflectional patterns;
b) differential object marking;
c) change of the basic word order from svo to sov in several envi- ronments;
d) loss of grammatical gender distinctions. ${ }^{11}$

\subsection{Griko: a Brief Description}

Griko is a Greek dialect spoken in South Italy, namely in the Salento area of Puglia (cf. Karanastasis 1984; Rohlfs 1977). ${ }^{12}$ Its sociolinguistic status has varied through centuries and till the early gos. Although the dialect seemed to be resisting to language shift, it was reported to be confined to only nine

11 Cf. Dawkins 1916; Thomason \& Kaufman (1988: 215-222); Janse, 1999, 2007, 2008, 2009, forthcoming; Johanson, 2002; Winford, 2005, 2010; Karatsareas, 2009, 2011, 2014; Ralli 2009.

12 Another Greek variety is still spoken in Calabria, not very different from Griko; it is usually called Greko. The two varieties, Griko and Greko, are referred together as Grekanico or simply Italiot. 
Griko-speaking villages ${ }^{13}$ (cf. Profili, 1985), and mainly among people of advanced age. Being spoken for a long period on Romance ground, ${ }^{14}$ Griko has been in a long-term contact with Italo-Romance, not only in its Italian form (the language of school and media in the last two centuries), but with the local Romance varieties (dialetti salentini) as well, which are used in every day speech (street conversations, local commerce). As a result, the domain of Griko was restricted to family situations (cf. Profili, 1985; Katsoyannou, 1999). According to Profili (1999) the speakers of Griko, and those of Grekanico in general, do not identify themselves as 'Greek.' They are Italian citizens and consider themselves to be Italian. Nevertheless, the dialect constitutes for them a close link to their Greek historical roots and neighbours in terms of 'mentality' and culture - without having actual kinship or ethnic ties with Greece.

As for Cappadocian with respect to Turkish, the influence of Italo-Romance on Griko is evident on all levels of grammar. For example, the usage of the Romance periphrastic construction 'steo 'to stand' + gerund, for the expression of progressive aspect, e.g. steo grafonta 'I am writing' (cf. Katsoyannou, 1995), or the re-structuring of nominal inflection leading to a more simplified organization of inflectional paradigms and case markers, as compared to those of Modern Greek (cf. Melissaropoulou, 2014, 2017), are clear cases of structural interference or contact induced grammaticalization.

Borrowability of Free Grammatical Elements: A Contrastive Approach

In this section, a systematic overview of the free grammatical elements under scrutiny and their origin is provided. Tables 1 and 2 summarize all different categories of free grammatical elements in Cappadocian and Griko respectively. The attested types are provided in italics, their interpretation is given in single quotation marks, followed by the corresponding form in the model language. ${ }^{15}$

Information organized in the tables above leads to the generation of the borrowability scales shown in Figures 1 and 2 for each one of the dialects under

13 Calimera, Castrignano dei Greci, Corigliano di Otranto, Martano, Martignano, Melpignano, Soleto, Sternatia, and Zollino.

14 See Minas (1994, 2004), Manolessou (2005) and references therein for different opinions with respect to its origin, that is, being descendant from Ancient Greek or Byzantine Greek.

15 Turkish and Italo-Romance data are exemplified as they appear in written sources. 
TABLE 1 Free grammatical elements in Cappadocian borrowed from Turkish ${ }^{16}$

\begin{tabular}{|c|c|c|c|}
\hline Adverbials (32) & $\begin{array}{l}\text { Space (3) } \\
\text { Quantifiers (8) }\end{array}$ & $\begin{array}{l}6 . \\
7 . \\
8 . \\
9 . \\
10 . \\
11 . \\
12 . \\
1 . \\
2 . \\
3 . \\
1 . \\
2 . \\
3 . \\
4 . \\
5 . \\
6 . \\
7 . \\
8 .\end{array}$ & 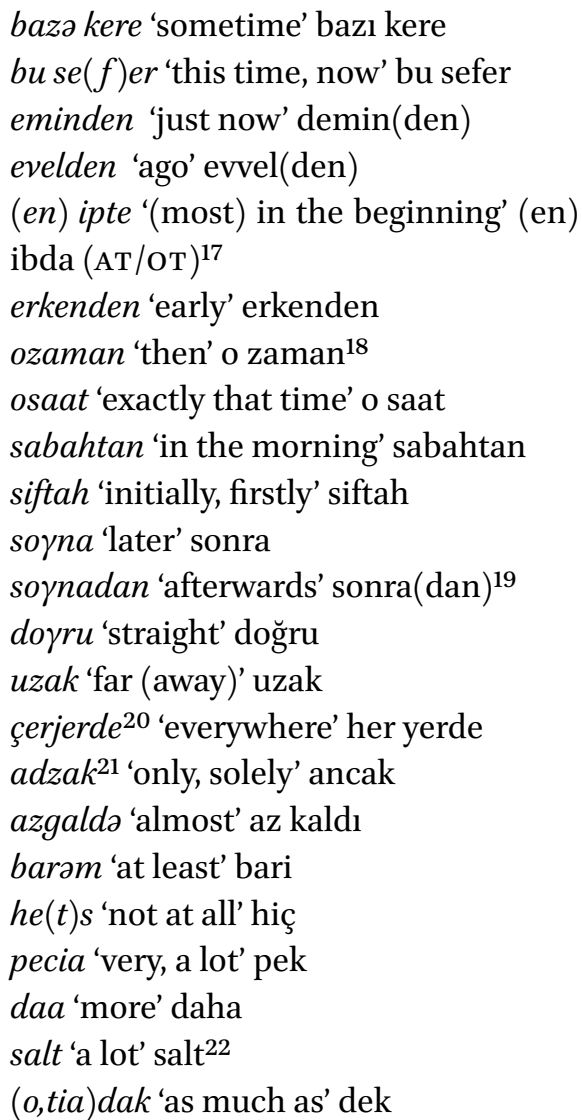 \\
\hline
\end{tabular}

16 For clarity reasons, Turkish (Tr) is not noted. On the contrary, if the examples come from Anatolian Turkish or Ottoman Turkish are noted as AT and OT, respectively.

17 Even though ibda does not exist in Modern Turkish, it is found in Ат and от, bearing the meaning 'beginning, creation' (Bağrıaçlk, personal communication).

18 zaman expresses in Turkish the content of the first conjunct as a knowable condition, which is assumed to be fulfilled.

19 In the adverbial sonradan 'after the event', '(only) afterwards', the ablative case marking dan has the opposite effect of drawing the attention to the lateness of the occurrence of an event (Göksel and Kerslake 2005: 202).

20 her yerde in Turkish is a periphrastic formation meaning 'in every place'.

21 adzak is also used in the South-Eastern Cappadocian community of Ulaghátsh as a temporal adverb, meaning 'just'. E.g. adzak irta '(I) just came'.

22 The form salt means 'only, solely' and by extension 'a lot'. 
TABLE 1 Free grammatical elements in Cappadocian borrowed from Turkish (cont.)

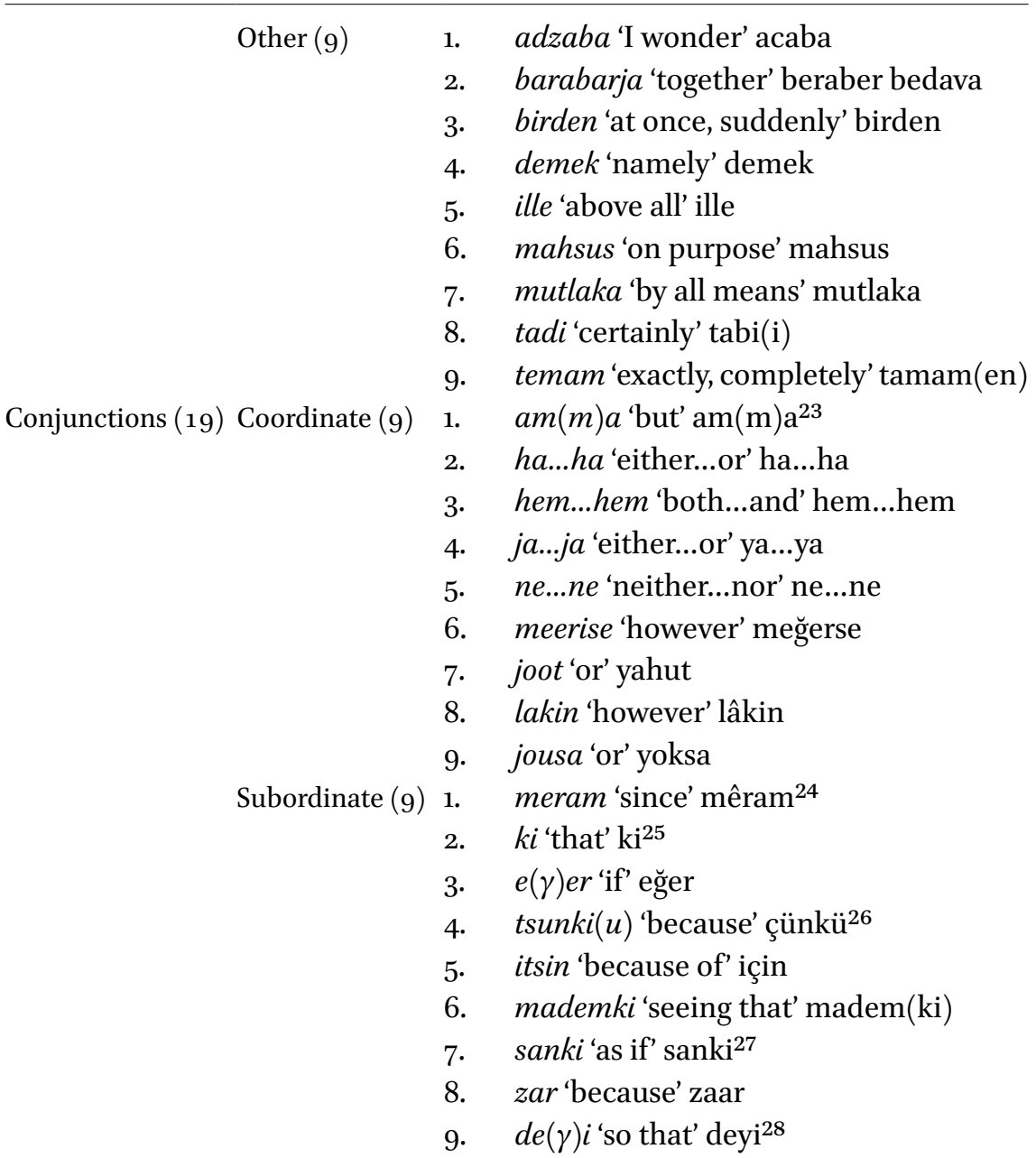

23 In Standard Turkish it is written with one ' $m$ '.

24 In central Anatonial dialects mêram is used with the meaning 'if so, if it is the case'.

25 Cf. Bağrıaçı (2018).

26 The form çünkü is placed in Turkish both at the beginning and at the end of causal clauses (Göksel and Kerslake 2005: 452).

27 Following Göksel and Kerslake (2005: 403) the "addition of the subordinating conjunction sanki 'as if' at the beginning of the clause [in Turkish] provides early warning to the hearer of the non-factual status of the content of the clause".

28 Cf. Bağriaçık and Göksel (2016). 


\begin{tabular}{|c|c|c|c|}
\hline \multirow[t]{3}{*}{ Particles (3) } & & 1. & ma 'question particle' mi \\
\hline & & 2. & ha 'at least' ha \\
\hline & & 3. & taman 'emphatic particle'29 tamam \\
\hline \multirow[t]{4}{*}{ Pronouns $^{30}(4)$} & & 1. & her 'every' her \\
\hline & & 2. & baska '(an)other' başka \\
\hline & & 3. & seis 'that (person)' şey \\
\hline & & 4. & herkis 'everybody' herkes \\
\hline \multirow[t]{4}{*}{ Numerals (4) } & Cardinals (1) & 1. & juz 'hundred' yüz \\
\hline & Ordinals (3) & 1. & birindzi 'first' birinci \\
\hline & & 2. & icindzi 'second' ikinci \\
\hline & & 3. & ütfündzü 'third' üçüncü \\
\hline
\end{tabular}

investigation. Each scale is formulated on quantitative terms, based on the number of items that each category includes in descending order, that is, beginning with the more numerous category at the left. Categories which score the same number of members are separated with commas. Scales will be discussed in section 5 .

TABLE 2 Free grammatical elements in Griko $31 / 32$

$\begin{array}{lll}\text { Adverbials (16) Time (9) } & \text { 1. } & \text { (a)poi 'afterwards' poi (IT) } \\ & 2 . & \text { allora } 33 \text { 'then' allora (IT) } \\ 3 \cdot & \text { appena 'as soon as' appena (IT) } \\ 4 \cdot & \text { viata 'always' viatu (R) } \\ 5 \cdot & \text { mai 'never' mai (IT) } \\ 6 . & \text { doppu 'after(wards)' doppu (R) } \\ 7 \cdot & \text { tarda 'late' tardi (IT) } \\ \text { 8. } & \text { presta 'early' presto (IT) } \\ 9 \cdot & \text { ankora 'still' ancora (IT) }\end{array}$

29 Cf. Bağrıaçık (2018).

30 A narrow definition of pronouns would include in this category only personal pronouns. Nevertheless, for the purposes of this study, we chose to adopt a more loose conception of the term and include other traditionally termed pronominal elements, such as the deictic pronoun, seis 'that (person)', since it can have a pronominal function and substitute a noun. Discussion on the status of the members of this category is found in section 5.2 .

31 The source forms of loan grammatical elements in Griko are marked as R, if they come from the (R)omance varieties.

32 On the italianization of function word systems of the autochthonous minority languages of Italy, Grekanico included, see Stolz (2005).

33 Cf. Stolz (2007). 
TABLE 2 Free grammatical elements in Griko ${ }^{31 / 32}$ (cont.)

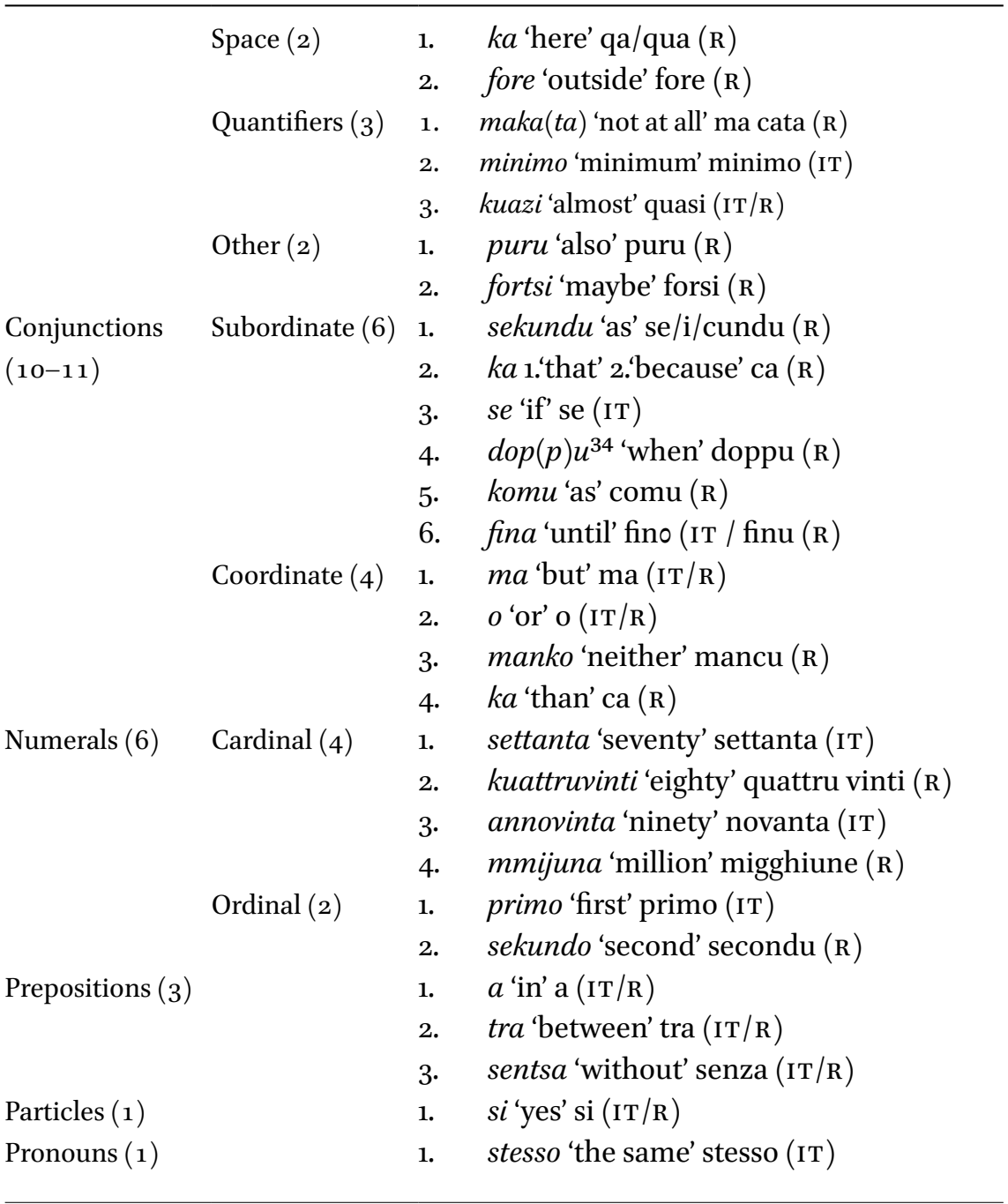

34 Apart from its adverbial use, dорри осcurs as a temporal subordinator as well, bearing the meaning 'when'. E.g.

An valome nnero poddine dop $(p) u$ dzimonnome, to ssomi erkete apalo.

If put.1pl water a lot when knead.1pl the bread come.3s soft.

'If we put a lot of water when we knead, the bread becames soft' 
Adverbials > conjunctions (co-ordinate, subordinate) > particles, pronouns, numerals

FIGURE 1 Cappadocian borrowability scale

Adverbials $>$ conjunctions (subordinate $>$ co-ordinate) $>$ numerals $>$ prepositions $>$ particles, pronouns

FIGURE 2 Griko borrowability scale

\section{$5 \quad$ Discussion}

\subsection{Congruence of Cappadocian and Griko borrowability scales}

A contrastive look at the two borrowability scales leads us to a number of observations. First, we observe that in both case studies adverbials are placed at the highest position of the borrowability scale. This should not come as a surprise, because sentential adverbials constitute a category of a more lexical and less grammatical nature, forming a less closed-class category as compared to other grammatical elements, such as pronouns, determiners and auxiliaries. As regards the ranking of the borrowability of adverbials, our data corroborate the claim that place adverbials, place deixis in particular, seem to be more resistant to borrowing compared to other categories, more specifically compared to time adverbials (cf. Matras, 2007). Only two adverbs have been traced in Cappadocian, doyru 'straight' < TR doğru and uzak 'far(away)' < TR uzak and two in Griko, $k a$ 'here' < R qa/qua and fore 'outside' < $\mathrm{R}$ fore, compared to the corresponding sub-category of time adverbials which outnumbers many more members, that is, 12 and 8 numbers, respectively.

Second, conjunctions occur at the second rank regarding the borrowability cline. This finding is in accordance with Matras $(1998,2007)$ who argues that connectors are by far the most susceptible category to borrowing, as attested in the 27 different languages of his sample.

Third, auxiliaries and determiners are not borrowed although in both case studies categorization of free grammatical elements was anticipated. The zero borrowability of determiners and auxiliaries in contrast with the high borrowability of adverbials in the two dialects seem to align with and depict in general the different places that these categories hold on the already mentioned cline of lexicality, proposed by Jackson (1988) (and revised by Xydopoulos, 2008 
for Greek). ${ }^{35}$ Namely, auxiliaries ${ }^{36}$ and determiners, which are placed at the rightmost end of the cline of lexicality and are argued to have a more grammatical status than all the other categories, are those not susceptible to borrowing.

Lastly, in both case studies, particles and pronouns freely alternate and occupy the last position of the respective borrowability scale. Thus, they seem to be more resistant to borrowing than the preceding categories. Nevertheless, their free alternation and qualitative differences in terms of membership in each different dialectal system force us to elaborate on them below, when emphasizing dissimilarities. These findings summarize all established similarities on the borrowability scale of our study. The rest of the categories, that is, adpositions, quantifiers, particles, pronouns and numerals do not show a uniform behaviour.

\subsection{Disagreement between Cappadocian and Griko borrowability scales}

With respect to dissimilarities, we note that the two scales do not converge as regards the internal hierarchy of the category of conjunctions. In Cappadocian, coordinate conjunctions do not outrank subordinate ones, as expected according to Muysken's $(1981,2014)$ scale, showing that subordinate conjunctions are more susceptible to borrowability. Interestingly in Griko, the reverse ordering seems to be at play, that is, subordinate conjunctions outrank

35 According to this cline four different grades are provisioned as follows: the first one contains nouns, verbs, adjectives and manner adverbs, the second contains prepositions, conjunctions, quantifiers, and sentential adverbs, the third pronouns, deixis, and possessives, while the last one determiners and auxiliaries. The members of the first grade, placed at the leftmost end of the continuum, are considered to be the most lexical ones, while those of the fourth, placed at the rightmost end of the continuum, are seen as the most grammatical ones, the other grades being in between.

36 The only case that may be a counter-example is the transfer to Griko of the structural pattern ste $(k) o+$ gerund in -onda (e.g. ste ( $k / g)$ o yrafonda 'I am writing', steo pentseonda 'I am thinking'), for the realization of the continuous present, containing the verbal ItaloRomance form ste(k)o, which could be argued to serve as an auxiliary verb. However, treating $s t e(k) o$ as a loan auxiliary form is controversial: although the verb in its realization as steo -that is, without the inter-vocalic consonant, is formally similar to the ItaloRomance verb stare 'to stand' and the corresponding structural pattern stare + gerund in -ndo (e.g. sto facendo 'I am doing'), it comes from the Greek native verb ste $(k / g) o$, which is systematically found in the dialect not only in the Present Indicative -in which a formal coincidence between the two systems occurs- but also in other verbal forms (e.g. the imperatives stasu / stasite 'stand.2SG/2PL'). This particular schema can be seen as an instance of pattern replication in terms of Sakel (2007). 
coordinate ones, calling for an explanation. Nevertheless, in neither case, subordinate conjunctions appear to be the less susceptible category to borrowability, as advocated in Muysken (1981).

In an effort to account for the divergence between the two case studies, we refer to the different characteristics of the two model languages. In fact, Turkish and Romance varieties diverge significantly in their strategies for denoting subordinate clauses: Turkish marks subordinate clauses with the use of postpositions, while Italo-Romance with the use of conjunctions, similarly to Greek. Some illustrative examples can be seen under (1), (2) and (3) below:

\section{Turkish}

(1) arka-sin-da back-POSS.3SG-LOC man be-SBJ.REL child 'the child behind whom there is a man' Göksel and Kerslake (2005: 382)

Italian

(2) Lui è tornato a casa sua, perché aveva un appuntamento he is returned at home his because had.3sg an appointment 'He went back home, because he had an appointment'

\section{Greek}

(3)

\begin{tabular}{|c|c|c|c|c|}
\hline $\begin{array}{l}\text { jirise } \\
\text { returned.3SG }\end{array}$ & $\begin{array}{l}s \text {-to } \\
\text { to-the }\end{array}$ & $\begin{array}{l}\text { spiti } \\
\text { home }\end{array}$ & $\begin{array}{l}\text { jati } \\
\text { because }\end{array}$ & $\begin{array}{l}\text { ixe } \\
\text { had.3SG }\end{array}$ \\
\hline
\end{tabular}
'He went back home, because he had work to do'

What can be seen from the above is that, in Griko, both the model and the replica language, that is, Italo-Romance and Greek, use the same strategy for the introduction of subordinate clauses. They both have subordinators placed at the beginning of the dependent clauses. On the contrary, in Cappadocian, there appears to be a significant divergence between the model and the replica system, that is, Turkish and Greek: Cappadocian does not have postpositions for the introduction of subordinate clauses, as opposed to Turkish which marks subordinate clauses mainly with the use of postpositions, and only in some cases with the use of subordinate conjunctions. As underlined by Göksel and Kerslake (2005), the Indo-European type of subordinate clauses, composed by a preceding subordinating conjunction and a finite verb, constitutes the only significant foreign grammatical influence to be seen in the Turkish language. More specifically, some of the Turkish subordinate conjunctions originate from Arabic (eğer 'if', madem ( $k i$ ) 'seeing that') and others from Persian ( $k i$ 'that', 
çünkü 'because'). Crucially, they seem to have been transferred to Cappadocian (see the respective column in Table 1) due to their structural compatibility with the Greek system.

Among the borrowed elements from Turkish in the specific category, the subordinator itsin 'because' < için is a unique example of a Turkish postposition that has entered the Cappadocian system, as a pre-posed conjunction. The postpositional use of için in the model language can be seen in the examples under (4) below:
(4) a. kim-in için
who-GEN.3SG for
'for whom'

b. bak-ma-dı̆̆-ım

look-NEG-FNOM-1SG

'Because I haven't looked/am/was notlooking.' Göksel and Kerslake (2005:85)
c. ver-mek için
give-INF for

'in order to give' Göksel and Kerslake (2005: 87)
d. o akşam misafir-ler-imiz ol-acağ-ı için yemek that evening guest-PL-POSS.1PL be-FUT.NOM-3PL because Dinner yap-mak-la meşgul-dü-k make-INF-INSTR

busy-PAST-1 PL

'As we were expecting guests that evening we were busy cooking'

Göksel and Kerslake (2005: 203)

This instance of borrowing in Cappadocian is of particular interest since it suggests that, although not frequently, it is not impossible for a purely functional element, such as an adposition, to be transferred to a language without the concomitant transfer of its structural features (that is, its linear ordering, contra Moravçsik 1978: 112). This item, however, must be accounted for in terms of reanalysis (cf. Siegel, 2000) or relabeling (cf. Lefebvre, 2008 and references therein for relevant discussion). In fact, relabeling is thought of as one of the major processes in language contact, which is mainly semantically driven if the two lexical entries (of the model and the replica language) involved in the process share some semantic similarity (see also Muysken, 1981 on this matter). However, in some cases, transfer may involve only a subset of features (cf. Lefebvre 2008: 95). This is the case of transfer of için 'because', where relabeling 
seems to have been activated on the basis of its meaning for the introduction of finite adverbial (causal) clauses. Nevertheless, instances of relabeling of adpositions do not abound in our case study.

The corresponding structure of the causal clause in the Cappadocian system can be seen under (5):

$\begin{array}{lllll}\text { (5) de } & \text { peniksan } & \text { skoleia } & \text { giai } & \text { dulivan } \\ \text { not } & \text { go.Past.3PL } & \text { school } & \text { because } & \text { were working.3PL }\end{array}$

'They did not go to school because they were working.'

Interestingly, in Griko, subordinate conjunctions outrank coordinate ones. This divergence, which is attested in other case studies as well (see Field, 2002 on Spanish borrowings in Modern Mexicano), should not come as a surprise since it can be easily ascribed to the ample repertoire of subordinate conjunctions in the Romance varieties (that is, causal, concessive, conditional, temporal, resultative, final, declarative, consecutive, comparative, modal, adversative, exclusive, privative, concessive), which are more numerous than those of coordinate ones (that is, copulative, explanatory, contrasting, conjunctions of sequence, declarative, concluding, comparative). Furthermore, their transfer is facilitated by the structural compatibility between the model and the replica language, in that in both languages, subordinate conjunctions bear the same structural features in terms of linear ordering and syntactic saliency (e.g. in a Chomskyan approach they hold the same position, being heads of functional phrases).

We would like to propose that the big number of borrowed coordinate or subordinate conjunctions could be viewed as an epiphenomenon, in the sense that, among quasi synonymous connectors, the most frequent ones, or the most typical of the area, would be the most powerful candidate(s) for contact induced transfer. We would further propose that the number of each different category of grammatical elements that enters the replica language is heavily determined by the structural characteristics of the two languages in contact and their respective (in)compatibility as well as by the relative repertoire of items of the model language. Therefore, it plays a crucial role for the formulation of the respective borrowability scale.

In a similar vein, we could account for another crucial difference concerning the borrowability of free grammatical elements, the presence of loan prepositions in Griko and their respective absence in Cappadocian. ${ }^{37}$ As already

37 The only element that could be considered as adpositional is tfax or tfaus 'up to, until' which, however, is not included in the present study due to its debatable origin either as 
mentioned, Moravçsik (1978: 112) has argued that grammatical elements (including at least conjunctions and adpositions) cannot be transferred to a replica language unless the structure determining the linear order with respect to the head is transferred as well. ${ }^{38}$ Crucially, Griko and Romance languages ${ }^{39}$ are both prepositional systems, thus, structurally compatible, in the sense that a loan prepositional element could easily fit into the replica system without the adoption of a diverging structure compared to the existing one, that is, the adoption of a different linear order of prepositions and NPs being necessary for the integration of innovative grammatical elements. On the contrary, in the case of Cappadocian, Turkish is of postpositional type, disfavoring transfer of the specific adpositional elements, unless specific re-arrangements are made in order for the innovative postpositional elements to fit into the replica language. Interestingly, according to Karatsareas (2013), although the functional subset of Turkish adpositions has been left intact, that is, proper postpositions have not been transferred to Cappadocian, Turkish adverbial elements can combine with Greek prepositions, but the construction undergoes a rearrangement, in that a circumposition has become an available option and circumpositional the default ordering, probably as a result of the replication of the Turkish adpositional pattern. An illustrative example of a circumpositional pattern can be seen under (6), where the combination of the Greek preposition se and the Greek article to, under the form of so 'at the', precedes the noun, while the Turkish adverbial element qarve 'opposite' follows it.

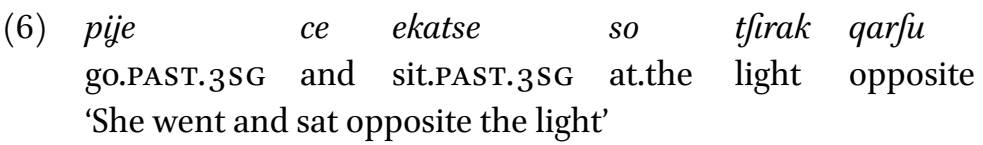

(Dawkins 1916: 346, cited in Karatsareas 2013)

Expanding this observation, we propose that, in cases like that under discussion, borrowability of free grammatical elements, in our case adpositions, is

a native element, deriving from $(e) t) t$ 'there' and the limitative $u s$, or as an instance of matter replication of the Anatolian Turkish postposition-affix -čaq (cf. Deny 1921: 614; Karatsareas 2013).

38 In Moravçsik's own terms: "A lexical item that is of the 'grammatical' type (which type includes at least conjunctions and adpositions) cannot be included in the set of properties borrowed from a language unless the rule that determines its linear order with respect to its head is also so included."

39 For the reverse situation, namely the transfer and the accommodation of a Romance preposition in a variety of languages see Stolz (2008: 23-25). 
captured more efficiently when it is interrelated with grammatical pattern replication (cf. Matras and Sakel, 2007), seen as a preparatory path for matter replication of grammatical elements. In other words, grammatical pattern replication or specific re-arrangements reconciling the structural incompatibility between the model and the replica language seem to be a prerequisite for the replication of grammatical elements.

Given the above, our data argue against Thomason's (2001) thesis that typological parameters do not govern contact induced change. On the contrary, our contrastive analysis predicts that if the co-existence of Cappadocian and Turkish had not been interrupted in 1924, due to the exchange of populations, matter replication involving the functional set of adpositions would have followed the observed grammatical pattern replication.

As regards numerals, our data do not provide a unified picture either. In Griko, they are placed third, outranking prepositions, pronouns, and particles, while in the Cappadocian borrowability scale they occupy the last position, being ranked together with particles and pronouns.

The general assumption in the existing literature is that numerals are placed low on the borrowing scale given that all languages display a system of quantification. However, according to Matras (2007: 51) the likelihood of borrowing numerals is subject to sociolinguistic constraints, since the dominant language is used in business transactions and institutional services. ${ }^{40}$ Matras (2007) argues that these circumstances favour higher numerals over lower ones. His prediction is the following:

(7) $1000,100>$ above $20>$ above $10>$ above $5>$ below 5

(Matras 2007: 51)

If we take into consideration the fact that, in everyday life, the use of low numerals is far more frequent than that of higher ones, we expect that in Griko and Cappadocian borrowing of low cardinal numbers will not be attested. Indeed, although the number of borrowed cardinal numbers is not the same in

40 Additionally, according to Matras (2010: 82) "Numerals are borrowed more often in formal contexts - for example when citing dates or commercial quantities, or in connection with commercial transactions - where they are associated with the language of the institutional domain and commerce. Among cardinal numerals, higher figures tend to be borrowed before lower figures, the latter being protected by the routine of everyday counting in the recipient language, the former being more typical of institutional settings (school, trade, administration, and so on". 
the two systems, higher numbers outrank lower ones. Nevertheless, in Cappadocian, only one number is borrowed, juz 'hundred', while in Griko, lower numbers such as, settanta 'seventy', kuattruvinti 'eighty', annovinta 'ninety', are attested along with the most highly ranked mmijuna 'million'. Moreover, the existing generalizations concerning the borrowability of ordinal numbers is verified by the Griko dialectal data, in that the attested primo 'first' and sekun$d o$ 'second' obey the generalization that the occurrence of higher ordinal numbers presupposes the occurrence of lower ones. Similarly, in Cappadocian (cf. Janse forthcoming, citing Mavrochalyvides and Kesisoglou 1960: 51) the three first forms, that is, first, second and third, are also attested.

Matras and Elsik (2006) interpret the high universality of low ordinals in terms of their 'structural conspicuousness' (their term), realized through lexical suppletion, and ultimately related to cognitive saliency. Thus, the high borrowability of low ordinal numbers is accounted for by the authors in terms of pragmatic saliency, referring to the need to separate one single entity from a larger set. Focusing on the dialectal data in hand, we would argue that borrowability of first and second in Griko is predictable in the light of their suppletive nature, that is, their formal absence from a larger set. In Cappadocian, although the formation of all ordinal numbers is realized with the attachment of the suffix -IncI and no suppletive forms are at play, the three first numbers are attested and can be accounted for in terms of cognitive saliency, as suggested by Elsík and Matras (2006). Nevertheless, only very low ordinals appear in both varieties.

Regarding the borrowability of pronouns, a contrastive look at the two dialects does not reveal a unified behaviour. In Griko, pronouns are placed at the end of the scale, with only one member, whereas in Cappadocian, although not much higher on the scale, they are ranked together with particles and numerals, displaying four members. Admittedly, in the literature, pronouns, personal ones in particular, and their respective paradigms are thought of as non-borrowable items because of their status as items of a closed set, and their tight structure as paradigms situated at the core of a linguistic system that cannot be disrupted (cf. Thomason and Everret, 200141; Dixon, 1997; Nichols and Peterson 1998). In most of these claims, the resistance to borrow pronominal paradigms is stressed and pronoun paradigms are considered among the

41 Thomason and Everett (2001) are right in arguing that social factors may determine the borrowability of pronouns. Borrowing of a specific type of inclusive or exclusive 'we', as noted by Thomason and Everett (2001), or of a different item for the realization of a form of courtesy or polite address we would add, cannot be predicted only by taking into consideration general linguistic principles. These kinds of transfer have been the outcome of heavy and long-term contacts of the involved systems. 
'surest indicators' of genetic affinity (Dixon 1997: 22). However, examples of adopted pronouns abound in the literature concerning Southeast Asian languages, Austronesian, Papuan languages and elsewhere (cf. Foley (1986: 210); Campbell (1997: 340)), and, in general, borrowing of individual pronouns is not said to be rare among loanwords in a great variety of languages (cf. Haspelmath and Tadmor 2009). Although some pronouns of both Cappadocian and Griko are listed on the two Tables displayed above, none of them belongs to the category of personal pronouns, and no pronominal paradigm has been traced. For instance, in Griko, in spite of the fact that the model language displays a vast repertoire of pronouns, the only borrowed member of the category is stesso 'self' which is a stressed reflexive pronoun, (e.g. Io lavo me stesso I wash myself'). However, it seems to operate like an adjective, since it does not replace but rather modifies nouns, as shown in the following examples:

$i \quad$ stessa jineka
the same.FEM woman.FEM
'the same woman/the woman herself'

$\begin{array}{lll}\text { to } & \text { stesso } & \text { spiti } \\ \text { the } & \text { same.NEU } & \text { house.NEU } \\ \text { 'the same house/the house itself' } & \text { Rohlfs (1977:96) }\end{array}$

In other words, this specific instance of pronoun borrowing in Griko could adequately be accounted for as an instance of adjective-like borrowing, adjectives being not particularly resistant to borrowing.

As already said, in Cappadocian, the range of borrowed pronominal elements is bigger, displaying four members. Interestingly, however, the items that are integrated and identified in the dialect as pronouns are not pronouns in the strict sense in Turkish and, crucially, they are not inflected, thus, not tightly structured into paradigms. Namely, her 'every' and başka '(an)other' are often labelled as uninflected determiners in Turkish, while herkes 'everyone' and sey 'thing' as uninflected pronominal quantifiers (cf. Kornfilt, 1997; Göksel and Kerslake, 2005). In our view, their uninflected nature along with their unbound form have acted as a facilitating factor for the transfer of these specific elements in Cappadocian, and their identification as indefinite pronouns on the basis of their semantics, bearing an adjective-like behavior. Crucially, in both dialects, all borrowed elements belong to the sub-group of pronouns viewed as more of the adjectival type, on the basis that they do not only substitute a noun but they often modify it, as is the case for adjectives.

Following these observations, both Cappadocian and Griko do not display real members of pronoun categories, lending support to the established claims 
in the literature that pronouns are resistant to borrowing (see among others Dixon, 1997; Nichols and Peterson 1998). Therefore, there is need for the reformulation of the borrowability scales, as follows:

Adverbials > conjunctions (co-ordinate, subordinate) > particles, numerals

FIGURE 3 Cappadocian borrowability scale revised

Adverbials $>$ conjunctions ( subordinate $>$ co-ordinate) $>$ numerals $>$ prepositions $>$ particles

FIGURE 4 Griko borrowability scale revised

Lastly, as regards particles, there is much controversy on both the definition and the members of this specific category. Whereas in typological studies the term has little or no status, in various grammatical descriptions and language-contact studies it is found quite often in use, but with very little consistency. Generally speaking, an element is categorized as particle on the basis of its invariable form, its grammatical or pragmatic meaning, its short length -usually monomorphemic-and does not fall easily under any of the traditional parts of speech. However, several sub-categories and respective labels have been recognized and proposed, such as adverbial particles, verbal particles, modal particles, focus particles, discourse particles, clitic particles, pronominal particles, and more. For the purposes of this study, we adopt a narrow definition of the term in the spirit of Bussman (1999: 867), excluding all invariant words, which in the replica languages are seen to belong to other grammatical categories, that is, adverbs, conjunctions, prepositions and interjections. ${ }^{42}$

In this perspective, a contrastive look at the two varieties of Greek does not reveal a significant divergence in the ranking of particles on the borrowability scales. Namely, in both Cappadocian and Griko, particles are placed on the ultimate position of the scale. In terms of absolute numbers, Cappadocian displays three members, while Griko only one. What should be borne in mind for this specific category is that, in the grammatical description of both

42 In Standard Modern Greek, the category of particles displays the following members: the deictic $n a$, the exhortative $j a$, the oathing-affirmative $m a$, the prospective-potential $\theta a$, the exhortative as, the yes/no particles ne, oxi, $\delta e(n), \operatorname{mi}(n)$.

43 However, in some recent syntax-oriented studies (cf. Coniglio, 2008) it has been proposed that some of the elements that are often considered as adverbs in Italian (e.g. mai 'never', 
model languages, ${ }^{43}$ the repertoire of the relevant items diverges significantly. According to Göksel and Kerslake (2005), Turkish has several different particles, shown under (9):

a. the negative particle değil

b. the particle ve, borrowed from Arabic, which conjoins all types of phrases and clauses

c. the particle keşke 'if only'

d. the question particle $m I$, which may host agreement markers in Turkish ${ }^{44}$

e. the particle bile 'even'

In Italian, on the other hand, following among others, Proudfoot and Cardo (2005), only two particles are generally recognized, namely $c i / v i$, with an adverbial or a pronominal meaning of 'here/there', and ne with a mainly partitive meaning - both occur as pure particles in several idiomatic expressions. Crucially in Italian, apart from $s i$ 'yes' and no 'no', particles seem to be more tightly structured and semantically opaque, as illustrated in the following example in

$\begin{array}{lll}\text { (10) } c e & \text { l' } & \text { hai? } \\ \text { PRT } & \text { it } & \text { have.2SG }\end{array}$

'Have you got it?'

which the contribution of ce cannot be easily detected:

Thus, in an effort to generalize on the borrowability of this specific category, we claim that the general tendency is that the narrow-defined category of particles has a low ranking on the borrowability scales. This behaviour is rather due to the fact that in the model languages particles belong to an extremely closed-class category, encompassing short-length items which do not fall within any other grammatical category.

\section{Conclusions}

To conclude, on the basis of our data, we would not argue in favour of any borrowability scale of generalized predictive power. This holds true even for

poi, 'after', pure 'also') display special characteristics and are worth scrutinizing and labelling as particles.

44 We thank an anonymous reviewer for highlighting this piece of information. 
cases with the same model or the same replica language and comparable social settings. On the contrary, our data offer further support to the idea that any borrowability scale is only representative of the particular modelreplica language pair that was used for its formulation, referring to a specific language-contact setting. Moreover, they do not seem to argue against the non-borrowability of pronominal paradigms and show that many grammatical categories do not come from contact induced transfer but result from genetic linguistic inheritance.

Contrary to Matras's (2007:66-68) assertion that the structure of the replica language plays a secondary role in determining borrowability scales and that only the functionality of categories and the extent of bilingual pressure hold the most prominent role, our data seem to suggest that the structural (in)compatibility parameter, the subsequent re-arrangements in the structure of the replica language, and each different category of grammatical elements may play a key role in the borrowability of free grammatical elements and the respective formulation of any borrowability scale.

Nevertheless, we argue against the thesis that borrowing of grammatical elements occurs only in cases of structural compatibility among the systems involved in a contact situation (contra Campbell 1993: 91). We align with Aikhenvald (2006: 26) who proposes that "diffusion of grammatical forms and patterns [can] be viewed in terms of a variety of facilitating factors or preferences." In this spirit, we propose that any hierarchy of borrowability should take into account typological criteria concerning not only the morpho-syntactic structure but also the distinction among different categories of grammatical elements in the involved systems (see also Rendon 2008: 71). In other words, we do not argue in favour of a universal hierarchy of borrowing but we rather speak of strong tendencies on the borrowability of specific categories. In our case, the general tendencies could be the high borrowability of adverbial elements and conjunctions, while the low susceptibility of borrowing particles, pronouns, and prepositions and the zero borrowability of determiners and auxiliaries depict, in general, the different places that these categories hold on the cline of lexicality. Thus, as regards Campbell's (1993: 100) claim that "borrowability of elements is based on the ranking of grammatical categories", we would say that no exact mirroring but general tendencies seem to play a role (see also Bakker et al. 2008 on contact of Spanish with Guaraní, Otomí and Quichua).

Finally, we would like to expand Matras's (2007: 35) claim that probably different explanatory accounts may be needed for interpreting the borrowability of different structural components, by adding 'different grammatical elements as well'. 


\section{Acknowledgements}

This research has been co-financed by the European Union (European Social Fund - ESF) and Greek national funds through the Operational Program "Education and Lifelong Learning" of the National Strategic Reference Framework (NSRF) - Research Funding Program: AR ISTEIA I, Investing in knowledge society through the European Social Fund (director Prof. Angela Ralli). An earlier, different in terms of analysis and much smaller version of this paper was presented at the 36th Annual Meeting of the Department of Linguistics, School of Philology, Aristotle University of Thessaloniki (April, 24-25, 2015), in collaboration with Michalis Marinis.

The authors are particularly indebted to Dr. Michalis Marinis for providing the data for this paper, and to Dr. Metin Bağriaçık for his most precious help concerning Turkish and the Anatolian dialects. They also wish to thank Henning Schreiber and an anonymous reviewer whose suggestions made this article benefit greatly.

\begin{tabular}{ll}
\multicolumn{1}{c}{ Abbreviations } \\
1 & $=$ first person \\
1 & $=$ second person \\
2 & $=$ third person \\
3 & $=$ feminine \\
FEM & $=$ factitive nominalizer \\
FNOM & future nominal \\
FUT.NOM & genitive \\
GEN & $=$ imperfective \\
IMPERF & $=$ infinitive \\
INF & $=$ instrumental \\
INSTR & $=$ locative \\
LOC & $=$ negation \\
NEG & $=$ neuter \\
NEU & $=$ past \\
PAST & $=$ plural \\
PL & $=$ possessive \\
POSS & $=$ present \\
PR & $=$ particle \\
PRT & $=$ singular \\
SG & $=$ subject relativizer \\
SUBJ.REL &
\end{tabular}




$\begin{array}{ll}\text { TEMP } & =\text { temporal } \\ \text { AT } & =\text { Anatolian Turkish } \\ \text { IT } & =\text { Italian } \\ \text { OT } & =\text { Ottoman Turkish } \\ \text { R } & =\text { Romance } \\ \text { TR } & =\text { Turkish. }\end{array}$

\section{References}

Aikhenvald, Alexandra. Y. 2006. Grammars in contact: A cross-linguistic perspective. In Alexandra Y. Aikhenvald \& Robert M. W. Dixon (eds.), Grammars in Contact: A Cross-linguistic Typology. Oxford: Oxford University Press, 1-66.

Bakker, Peter, Rendón, Jorge Gómez \& Hekking, Ewald. 2008. Spanish meets Guaraní, Otomí and Quichua: A multilingual confrontation. In Thomas Stolz, Dik Bakker \& Rosa Salas Palomo (eds.), Aspects of Language Contact. New Theoretical, Methodological and Empirical Findings with Special Focus on Romancisation Processes, edited by. Berlin, New York: Mouton de Gruyter, $165^{-238}$.

Bağriaçı, Metin. 2018. Pharasiot Greek: Word order and clause structure. Ph.D. dissertation. Ghent: Ghent University.

Bağnıaçı, Metin \& Aslı Göksel. 2016. Greek meets Turkish: Subordination strategies in Cunda Turkish. In Mine Güven, Didar Akar, Balkız Öztürk \& Meltem Kelepir (eds.), Exploring the Turkish linguistic landscape: Essays in Honor of Prof. Eser Erguvanlı Taylan. Studies in Language Companion Series. Amsterdam/Philadelphia: John Benjamins, $57-80$.

Bussman, Hadumod. 1999. Routledge Dictionary of Language and Linguistics. London and New York: Routledge.

Campbell, Lyle. 1993. On proposed universals of grammatical borrowing. In Henk Aertsen \& Robert J. Jeffers (eds.), Historical Linguistics 1989. Amsterdam/Philadelphia: John Benjamins, 91-109.

Campbell, Lyle. 1997. Amerindian personal pronouns: A second opinion. Language 73 (2), 339-351.

Coniglio, Marco. 2008. Modal particles in Italian. University of Venice Working Papers in Linguistics 18, 91-129.

Cassoni, Mario. 1999. Vocabolario Grico-Italiano. Lecce: Argo.

Dawkins, Richard. 1916. Modern Greek in Asia Minor: A study of the dialects of Silli, Cappadocia and Pharasa with grammar, texts, translations and glossary. Cambridge: Cambridge University Press.

Dixon, Robert M. W. 1997. The rise and fall of languages. Cambridge: Cambridge University Press. 
Deny, Jean. 1921. Grammaire de la langue turque (dialecte osmanli). Paris: Imprimerie nationale.

Elsík, Viktor \& Yaron Matras. 2006. Markedness and language change: The Romani sample. Berlin: Mouton de Gruyter.

Field, Fredric W. 2002. Linguistic borrowing in bilingual contexts. Amsterdam: John Benjamins.

Filieri, Giorgio. V. 2001. Ivò milò to griko [I speak Griko]. Ioannina: University of Ioannina, Center of Greek Language and Culture.

Foley, Willian. A. 1986. The Papuan languages of New Guinea. Cambridge: Cambridge University Press.

Göksel, Aslı \& Celia Kerslake. 2005. Turkish: A comprehensive grammar. London and New York: Routledge.

Haspelmath, Martin \& Uri Tadmor (eds.). 2009. Loanwords in the world's languages: A comparative handbook. Berlin: Mouton De Gruyter.

Haugen, Einar. 1950. The analysis of linguistic borrowing. Language 26, 210-31.

Haugen Einar. 1951. Directions in modern linguistics, Language 27, 211-222.

Heine Bernd \& Tania Kuteva. 2005. Language Contact and Grammatical Change. Cambridge: Cambridge University Press.

Janse, Mark. 1999. Greek, Turkish, and Cappadocian relatives revis(it)ed. In Amalia Mozer (ed.), Proceedings of the 3 rd international conference on Greek linguistics. Athens: Ellinika Grammata, 453-462.

Janse, Mark. 2007. De Cappadociërs en hun talen. Tetradio 16, 57-78.

Janse, Mark. 2008. Clitic doubling from Ancient to Asia Minor Greek. In Dalina Kallulli \& Liliane Tasmowski (eds.), Clitic Doubling in the Balkan Languages. Amsterdam/ Philadelphia: John Benjamins, 165-202.

Janse, Mark. 2009. Greek-Turkish language contact in Asia Minor. Études Helléniques/ Hellenic Studies 17 (1), 37-54.

Janse, Mark. forthcoming. Cappadocian. In Christos Tzitzilis (ed.) The Greek language and its dialects. Thessaloniki.

Johanson, Lars. 2002. Contact-induced linguistic change in a code-copying framework. In Mari C. Jones and Edith Esch (eds.), Language change: The interplay of internal, external and extra-linguistic factors. (Contributions to the Sociology of Language, 86). Berlin: Mouton De Gruyter, 285-313.

Jackson, Howard. 1988. Words and their meaning (Learning About Language). London/ NewYork: Longman.

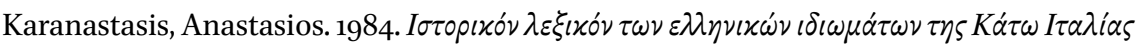
[Historical dictionary of the Greek dialects of South Italy], Vol 1. Athens: Academy of Athens.

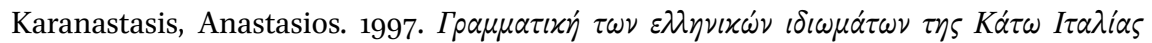
[Grammar of the Greek dialects of South Italy]. Athens: Academy of Athens. 
Karatsareas, Petros. 2013. Adpositional systems in contact: the case of Cappadocian Greek. Paper presented at the $46^{\text {th }}$ Annual Meeting of the Societas Linguistica Europaea (WS 21: Typology of adposition and case marker borrowing). Split University, 20-21 September 2013.

Karatsareas, Petros. 2009. The loss of grammatical gender in Cappadocian Greek. Transactions of the Philological Society 107 (2), 196-230.

Karatsareas, Petros. 2011. A study of Cappadocian Greek nominal morphology from a diachronic and dialectological perspective. Unpublished $\mathrm{PhD}$ thesis, University of Cambridge.

Karatsareas, Petros. 2014. On the diachrony of gender in Asia Minor Greek: The development of semantic agreement in Pontic. Language Sciences 43(1), 77-101.

Katsoyannou, Marianna. 1995. Le parler gréco de Gallicianò (Italie): description d'une langue en voie de disparition. Thèse de doctorat, Université de Paris VII - Denis Diderot.

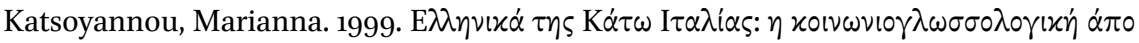
$\psi \eta$ [Greek in South Italy: the sociolinguistic view]. In Amalia Mozer (eds.), Greek Linguistics 97' Proceedings of the $3^{\text {rd }}$ International Conference on Greek Language. Athens: Ellinika Grammata, 605-613.

Kornfilt, Jaklin. 1997. Turkish. London: Routledge.

Lefebvre, Claire. 2008. Relabeling: A major process in language contact.Journal of Language Contact, 2, 91-111.

Manolessou, Ioanna. 2005. The Greek dialects of South Italy: an overview. CAMPOS: Cambridge Papers in Modern Greek (13), 103-125.

Matras, Yaron. 1998. Utterance modifiers and universals of grammatical borrowing. Linguistics 36, 281-331.

Matras, Yaron. 2007. The borrowability of grammatical categories. In Yaron Matras \& Jeanette Sakel (eds.), Grammatical borrowing in cross-linguistic perspective. Berlin: Mouton De Gruyter, 31-74.

Matras, Yaron. 2009. Language contact. Cambridge: Cambridge University Press.

Matras, Yaron. 2010. Contact, convergence, and typology. In Raymond Hickey (ed.), The handbook of language contact. Malden, MA/Oxford: Wiley-Blackwell, 66-85.

Matras, Yaron \& Janette Sakel. 2007. Investigating the mechanisms of pattern replication in language convergence. Studies in Language 31 (4), 829-865.

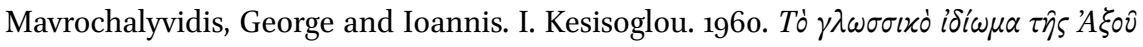
(Le dialecte d'Axos). Athens: Institut français d'Athènes.

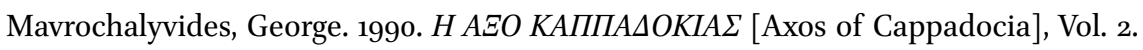
Athens: Center for Modern Greek Studies.

Meillet, Antoine. 1921. Linguistique historique et linguistique générale. Paris: Champion. Melissaropoulou, Dimitra. 2014. On the role of language contact in the reorganization of grammar: a case study on two Modern Greek contact induced dialects. In Proceedings of the $5^{\text {th }}$ international conference of Modern Greek dialects and linguistic 
theory, Ghent 20-22 September 2012. Downloadable at http://lmgd.philology .upatras.gr/files/MGDLT5_proceedings.pdf (accessed June 12, 2016).

Melissaropoulou, Dimitra. 2017. On the role of language contact in the reorganization of grammar: a case study on two Modern Greek contact induced dialects. Poznan Studies in Contemporary Linguistics, 53(3), 449-485. doi:10.1515/psicl-20170017.

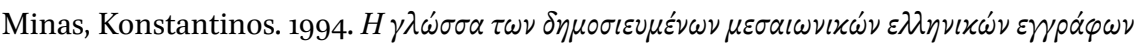

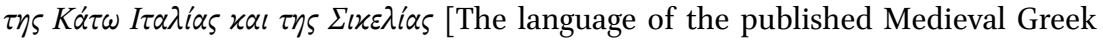
documents of South Italy and Sicily]. Athens: Academy of Athens.

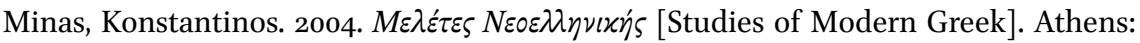
Typothito.

Moravçsik, Edith. 1975. Borrowed verbs. Wiener Linguistische Gazette 8, 3-30.

Moravcsik, Edith. 1978. Universals of language contact. In Joseph H. Greenberg (ed.), Universals of human language. Stanford: Stanford University Press, 94-122.

Muysken, Pieter. 1981. Halfway between Quechua and Spanish: the case for relexification. In Arnold Highfield \& Albert Valdman (eds.), Historicity and variation in Creole studies. Ann Arbor: Karoma, 52-78.

Muysken, Peter. 2010. Scenarios for language contact. In Raymond Hickey (ed.), The handbook of language contact. Malden, MA/Oxford: Wiley-Blackwell, 265-281.

Myers-Scotton, Carol. 2002. Contact linguistics: bilingual encounters and grammatical outcomes. Oxford: Oxford University Press.

Nichols, Joanna \& David A. Peterson. 1998. Amerindian personal pronouns: A reply to Campbell. Language 74, 605-614.

Profili, Olga. 1985. La romanisation d' un grec parler de l' Italie du Sud par les parlers romans environants. Actes du XVIIe congrés international de linguistique et de philologie romanes, Aix-en-Provence 29 août - 3 septembre 1983. Aix-en-Provence: Université de Provence, 129-139.

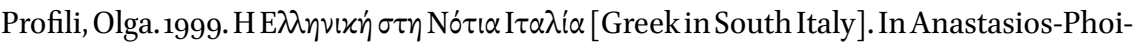

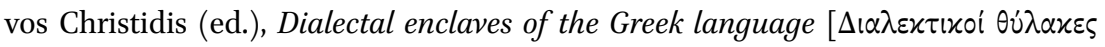
$\tau \eta \varsigma \varepsilon \lambda \eta \nu \iota x \eta \dot{\varsigma} \gamma \lambda \omega \dot{\omega} \sigma \alpha \varsigma]$. Athens: YРЕРTH-Centre for Greek Language, 31-37.

Proudfoot, Anna \& Francesco Cardo. 2005. Modern Italian grammar. London/New York: Routledge.

Ralli, Angela. 2009. Morphology meets dialectology. Insights from Modern Greek dialects. Morphology 19 (1), 87-105.

Ralli, Angela. 2016. Strategies and Patterns in loan verb integration in Modern Greek varieties. In A. Ralli (ed.), Contact morphology in Modern Greek dialects. Newcastle upon Tyne: Cambridge Scholars Publishing, 73-108.

Rendón Gómez, J.A. 2008. Typological and social constraints on language contact: Amerindian languages in contact with Spanish. Utrecht: LOT.

Rohlfs, Gerhard. 1977. Grammatica storica dei dialetti italogreci. München: C.H. Beck'sche Verlagsbuchhandlung. 
Sakel, Jeanette. 2007. Grammatical borrowing in cross-linguistic perspective. In Georg Bossong, Bernard Comrie \& Yaron Matras (eds.), Empirical Approaches to Language Typology. Berlin/New York: Mouton den Gruyter, 15-29.

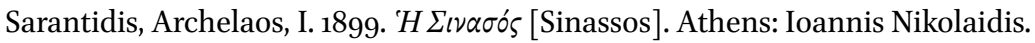

Siegel, Jeff (ed.). 200o. Processes of language contact. Studies from Australia and the South Pacific [Collection Champs linguistiques]. Montréal: Fides.

Stolz, Thomas. 2005. Italianisierung in den Alloglotten Sprachen Italiens. In Emerildo Bidese, James R. Dow \& Thomas Stolz (eds.), Das Zimbrische zwischen Germanisch und Romanisch. Bochum: Brockmeyer, 43-68.

Stolz, Thomas. 2007. Allora: On the recurrence of function-word borrowing in contact situations with Italian as donor language. In Jochen Rehbein, Christiane Hohenstein \& Lukas Pietsch (eds.), Connectivity in grammar and discourse. Amsterdam/ Philadelphia:John Benjamins, 75-100.

Stolz, Thomas. 2008. Romancisation worldwide. In Thomas Stolz, Dik Bakker \& Rosa Salas Palomo (eds.), Aspects of language contact. New theoretical, methodological and empirical findings with special focus on romancisation processes. Berlin, New York: Mouton de Gruyter, 1-42.

Stomeo, Paolo. 1996. Racconti greci inediti di Sternatia. Lecce: Edizioni "La nuova Ellade".

Stranzy, Philip (ed.). 2005. Encyclopedia of linguistics, volume I, A-L. Fitzroy Dearborn: New York.

Thomason, Sara Grey. 2001. Language contact. An introduction. Edinburgh: Edinburgh University Press.

Thomason, Sara Grey \& Terrence Kaufman. 1988. Language contact, creolization and genetic linguistics. Berkeley: University of California Press.

Thomason, Sarah G. \& Daniel L. Everett. 2001. Pronoun borrowing. Proceedings of the Annual Meeting of the Berkeley Linguistics Society, vol. 27, 301-315.

Tommasi, Salvatore. 1996. Katalisti o kosmo. Ghetonia: Kalimera.

Vryonis, Spiros Jr. 1971. The decline of Medieval Hellenism in Asia Minor and the process of islamization from the eleventh through the fifteenth century. Berkeley: University of California Press.

Winford, Donald. 2003. An introduction to contact linguistics. Oxford: Blackwell.

Winford, Donald. 2005. Contact-induced changes: classification and processes. Diachronica 22, 373-427.

Winford, Donald. 2010. Contact and borrowing. In Raymond Hickey (ed.), The handbook of language contact. Malden, MA/Oxford: Wiley-Blackwell, 170-187.

Whitney, William D. 1881. On mixture in language. Transactions of the American Philological Association (1869-1896), 5-26.

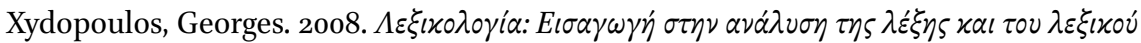
[Lexicology: an introduction to the analysis of the word and the lexicon]. Athens: Patakis. 